\title{
Conversion of Curcumin into Heterocyclic Compounds as Potent Anti-diabetic and Anti-histamine Agents
}

\author{
Sara Nabil, ${ }^{a, b}$ Soheir N. Abd El-Rahman, ${ }^{* a, c}$ Suhailah S. Al-Jameel, ${ }^{a}$ and Asma M. Elsharif ${ }^{a}$ \\ ${ }^{a}$ Department of Chemistry, College of Science, Imam Abdulrahman Bin Faisal University; P.O. Box 1982, Dammam \\ 31441, Saudi Arabia: ${ }^{b}$ Department of Chemistry, Faculty of Science, Al-Azhar University (Girls Branch); Egypt: and \\ ${ }^{c}$ Crops Technology Research Department, Food Technology Research Institute, Agricultural Research Center; Giza- \\ Egypt. \\ Received March 1, 2018; accepted March 29, 2018; advance publication released online April 12, 2018
}

\begin{abstract}
Potential biologically active derivatives of the curcumin were prepared by the cyclocondensation reaction cyclohexanone 2, imino pyrimidine 3, pyrmidinones 4, thiopyrimidine 6 and pyranone 5, 7 when treated with acetylacetone, guanidine, ureaethylcyanoacetate, thiourea and ethylacetoacetate, respectively. The structures of compounds (2-7) were elucidated by means of microanalysis as well as spectral measurements such as IR, ${ }^{1} \mathrm{H}-\mathrm{NMR}$, MS. The anti-diabetic potential of curcumin derivatives were evaluated by assessing amylase inhibition assay, also inhibition of histamine release activity of curcumin derivatives were assessed by $\mathbf{U} 937$ human monocytes. The results for amylase inhibition activity revels that the curcumin inhibits $\alpha$-amylase in a concentration dependent manner. Compounds 4 and 5 exhibited significant inhibitory activity against amylase enzyme and was comparable with that of acrabose. Also, compounds 5, 6 and 7 exhibited significant inhibitory activity against histamine. Our results concluded that curcumin pyrmidinones and pyranone derivatives have highly effects as anti-diabetic and anti-histamine activities.
\end{abstract}

Key words curcumin; pyrimidine; pyranone; cyclohexanone derivative; anti-diabetic; anti-histamine

Curcumin, which imparts the yellow color to curry, is a natural product of the spice turmeric, Curcuma longa L. (Zingiberaceae). Curcumin exhibits a variety of pharmacologic activities, including anti-inflammatory, anticancer, antioxidant, wound-healing, antimicrobial effects, ${ }^{1)}$ antiallergic activity $^{2,3}$ and inhibits degranulation of the RBL-2H3 tumor mast cell line in culture. ${ }^{4,5)}$ Also, it prevents biliary disorders, anorexia, coughs, diabetes, hepatic disorders, rheumatism, sinusitis, cancer and Alzheimer's disease. ${ }^{6,7)}$

The ethyl acetate extract of Curcuma longa L. and curcumin were found to decrease histamine release from mast cells by blocking intracellular signalling events in mast cells. The anti-allergy activities of curcumin and curcumin-related compounds in relation to their antioxidant activities. Most of these compounds were shown to inhibit histamine release from RBL-2H3 cells induced by concanavalin A or a calcium ionophore. ${ }^{8)}$

Flavonoid-rich fractions of plants have been reported to be effective as antihyperglycemic and antihyperlipidemic agents in animal models of diabetes. ${ }^{9)}$ Plants derived polyphenols such as quercetagetin, fisetin and quercetin, which belong to the flavonoid family have been shown to be effective inhibitors of mammalian alpha-amylase with $\mathrm{IC}_{50} \mathrm{~S}$ in the order of micromolar. ${ }^{10)}$ Since curcumin (1,7-bis(4-hydroxy3-methoxyphenyl)-1,6-heptadiene-3,5-dione) could be viewed as a flavonoid of polyphenolic compounds, in this investigation we researched the inhibitory effect of curcumin on $\alpha$-amylase and the effect of curcumin orally on blood glucose levels in streptozotocin (STZ) induced diabetic and normal rats. $^{11)}$

Pyrimidines exhibit a wide broad as biologically active agents they showed antioxidant, ${ }^{12)}$ antifungal, ${ }^{13)}$ antibacterial, ${ }^{14)}$ antihypertensive, ${ }^{15)}$ antitumor, ${ }^{16)}$ activity. Also pyranone which is six membered oxygenated unsaturated ester heterocyclic compounds that shares chemical and physical properties reminiscent of alkene and aromatic compounds showed a wide range of biological activity as antileukemic, ${ }^{17}$ ) antitumor, ${ }^{18)}$ anti-fungal ${ }^{19)}$ inhibiting, human immunodeficiency virus (HIV) protease $\mathrm{e}^{20)}$ qualities also it was found that In the last several decades, cyclohexenone derivatives have received considerable attention due to their wide range of applications. Cyclohexenone derivatives exhibit antitumor, ${ }^{21)}$ anti-bacterial, ${ }^{22)}$ antimicrobial $^{23}$ ) agents this promoted the author to convert curcumin into this newly heterocyclic derivatives to enhance its biological activity.

\section{MATERIALS AND METHODS}

All melting points are uncorrected. IR spectra $(\mathrm{KBr})$ were recorded with a PerkinElmer, Inc. Spectrum RXIFT-IR system. ${ }^{1} \mathrm{H}-\mathrm{NMR}$ were measured with a Varian Gemini $200 \mathrm{MHz}$ instrument using tetramethylsilane (TMS) as internal standard and mass spectra were measured with a Shimadzu GC-MSQP 100 EX mass spectrometer.

Synthesis of 6-Acetyl-3,5-bis(4-hydroxy-3-methoxystyryl)cyclohexa-2,4-dienone (2) A mixture of $\mathbf{1}(0.01 \mathrm{~mol})$ and acetylacetone $(0.01 \mathrm{~mol})$ in ethanol $(50 \mathrm{~mL})$ was refluxed for $6 \mathrm{~h}$ and left to cool. The separated solid was filtered off, washed with ethanol, dried and recrystallized from acetic acid. Yield $85 \%$ and melting point (mp) $198^{\circ} \mathrm{C}$.

Analysis of $2 \mathrm{C}_{26} \mathrm{H}_{24} \mathrm{O}_{6}$ (432) (\%) Calcd for C, 72.21; $\mathrm{H}$, 5.59. Found: C, 72.18; H, 5.62.

Synthesis of $4,4^{\prime}-\left(1 E, 1^{\prime} E\right)-2,2^{\prime}$-(2-Imino-1,2-dihydropyrimidine-4,6-diyl)bis(ethene-2,1-diyl)bis(2-methoxyphenol) (3) A mixture of $1(0.01 \mathrm{~mol})$ and guanidine. $\mathrm{HCl}$ $(0.01 \mathrm{~mol})$ in ethanol $(50 \mathrm{~mL})$ was refluxed for $6 \mathrm{~h}$ and left to cool. The separated solid was filtered off, washed with ethanol, dried and recrystallized from acetic acid. Yield 85\% and 
mp $204^{\circ} \mathrm{C}$.

Analysis of $3 \mathrm{C}_{22} \mathrm{H}_{21} \mathrm{~N}_{3} \mathrm{O}_{4}$ (391) (\%) Calcd for C, 67.51; H, 5.41; N, 10.74. Found: C, 67.55; H, 5.40; N, 10.71.

Synthesis of 4,6-Bis $((E)-4$-hydroxy-3-methoxystyryl)pyrimidin-2(1H)-one (4) A mixture of $1(0.01 \mathrm{~mol})$ and urea $(0.01 \mathrm{~mol})$ in ethanol $(50 \mathrm{~mL})$ was refluxed for $6 \mathrm{~h}$ and left to cool. The separated solid was filtered off, washed with ethanol, dried and recrystallized from ethanol. Yield 78\% and $\mathrm{mp}$ $217^{\circ} \mathrm{C}$.

Analysis of $4 \mathrm{C}_{22} \mathrm{H}_{20} \mathrm{~N}_{2} \mathrm{O}_{5}$ (392) (\%) Calcd for C, 67.34; H, 5.14; N, 7.14. Found: C, 67.40; H, 5.10; N, 7.12.

Synthesis of 3-Acetyl-4,6-bis $((E)-4-h y d r o x y-3-m e t h o x y-$ styryl)-2 $\boldsymbol{H}$-pyran-2-one (5) A mixture of 1 ( $0.01 \mathrm{~mol})$ and ethylacetoacetate $(0.01 \mathrm{~mol})$ in ethanol $(50 \mathrm{~mL})$ was refluxed for $6 \mathrm{~h}$ and left to cool. The separated solid was filtered off, washed with $\mathrm{H}_{2} \mathrm{O}$, dried and recrystallized from ethanol. Yield $68 \%$ and $\mathrm{mp} 253^{\circ} \mathrm{C}$.

Analysis of $5 \mathrm{C}_{25} \mathrm{H}_{22} \mathrm{NO}_{7}$ (434) (\%) Calcd for C, 69.12; H, 5.10. Found C, 69.00; H, 5.23.

Synthesis of 4,6-Bis((E)-4-hydroxy-3-methoxystyryl)pyrimidine-2(1H)-thione (6) A mixture of $1(0.01 \mathrm{~mol})$ and thiourea $(0.01 \mathrm{~mol})$ in $N, N$-dimethylformamide (DMF) $(50 \mathrm{~mL})$ was refluxed for $6 \mathrm{~h}$ flitter while hot. The separated solid, washed with ethanol, dried and recrystallized from ethanol. Yield $74 \%$ and $\mathrm{mp} 228^{\circ} \mathrm{C}$.

Analysis of $6 \mathrm{C}_{22} \mathrm{H}_{20} \mathrm{~N}_{2} \mathrm{O}_{4} \mathrm{~S}$ (408) (\%) Calcd for C, 64.69; H, 4.94; N, 6.86; S, 7.85. Found: C, 64.74; H, 5.00; N, 6.82; S, 7.83 .

Synthesis of 5-(1-(4-Bromophenyl)ethylidene)-4,6-bis((E)4-hydroxy-3-methoxystyryl)-2-oxo-5,6-dihydro-2H-pyran3-carbonitrile (7) A mixture of $1(0.01 \mathrm{~mol}),(0.01 \mathrm{~mol})$ of $p$-bromoacetophenone, and ethylcyanoacetate $(0.01 \mathrm{~mol})$ in sodium ethoxide $(0.5 \mathrm{~g}$ in $20 \mathrm{~mL})$ was refluxed for $5 \mathrm{~h}$. The solid product that separated after cooling and pouring into ice was filtered off, washed well with water, dried and recrystallized from EtOH. Yield $77 \%$ and $\mathrm{mp} 250^{\circ} \mathrm{C}$.

Analysis of $7 \mathrm{C}_{32} \mathrm{H}_{26} \mathrm{BrNO}_{6}$ (599) (\%) Calcd for C, 64.01; H, 4.36; Br, 13.31; N, 2.33. Found: C, 63.98; H, 4.38; Br, 13.29; N, 2.36 .

Biological Assessment All chemicals were received from Sigma-Aldrich (St. Louis, MO, U.S.A.).

Determination of $\alpha$-Amylase Inhibitory Activity

We used the assay of colorimetric microplate to determined the activity of $\alpha$-amylase inhibitory by utilizing a well-established protocol. ${ }^{24}$ ) The reaction of enzyme consisted of $4 \mathrm{mg}$ $\alpha$-amylase of porcine pancreatic (type VI-B, $\geq 10$ units/mg solid), $1.25 \mathrm{~mm} p$-nitrophenyl- $\alpha$-D-maltopentaoside (PNPG-5) and $1 \mathrm{mg}$ of samples in the 96 -well plate. The microplate reader was using to monitor the reaction of enzyme at $405 \mathrm{~nm}$. The following equation was using to calculated the percentage of $\alpha$-amylase inhibition:

Equation

$$
\% \text { inhibition }=(\text { Abs control }- \text { Abs sample }) \times 100
$$

\section{Abs Where}

Abs control=absorbance of control reaction.

Abs sample $=$ absorbance of test sample.
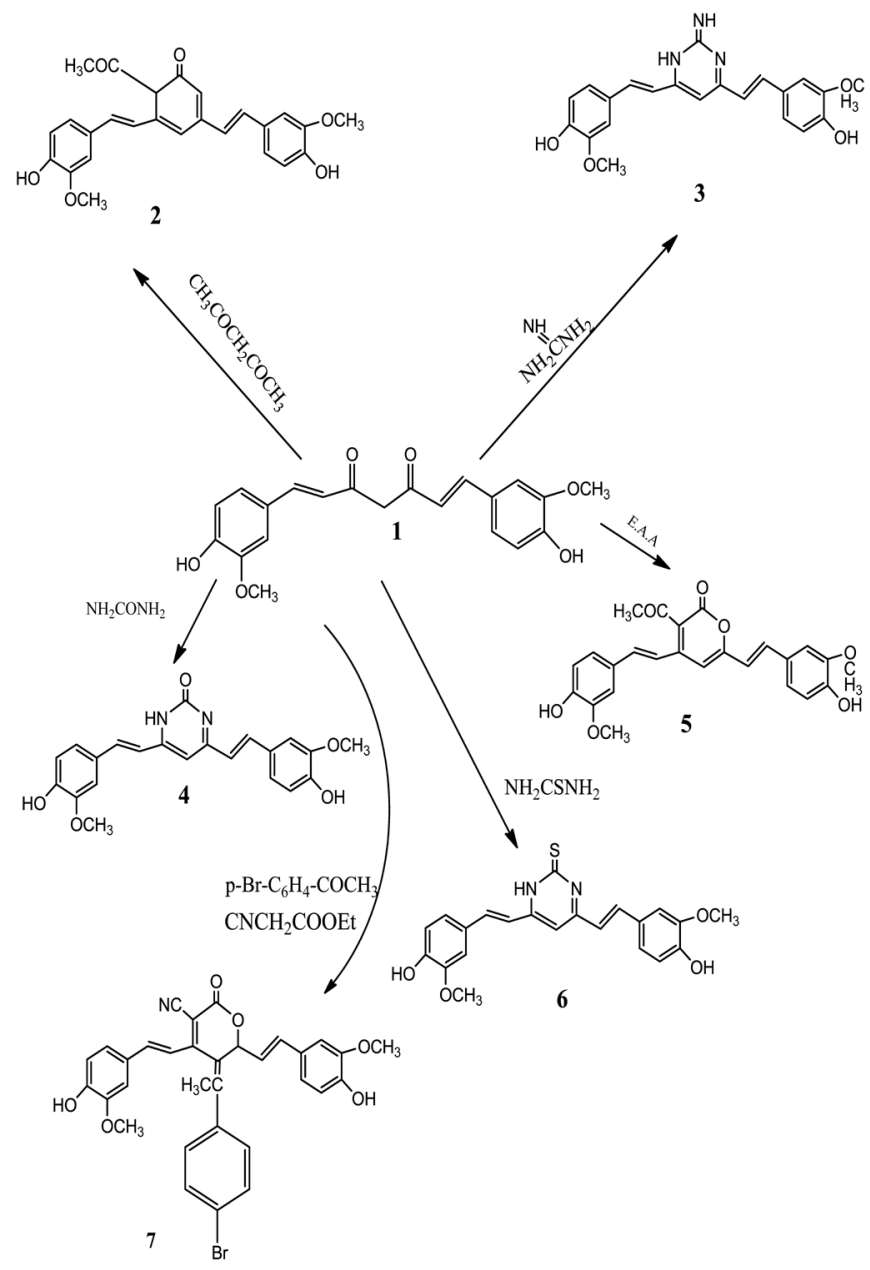

Chart 1

Table 1. $\alpha$-Amylase Inhibitory of Curcumin Derivatives

\begin{tabular}{|c|c|c|c|c|c|c|c|c|c|}
\hline Sample conc. $(\mu \mathrm{M})$ & 7.81 & 15.63 & 31.25 & 62.5 & 125 & 250 & 500 & 1000 & $\mathrm{IC}_{50}$ \\
\hline Control (acarbose) & $37.81 \pm 1.20$ & $40.75 \pm 1.50$ & $48.84 \pm 1.20$ & $59.31 \pm 1.50$ & $60.17 \pm 0.63$ & $69.37 \pm 1.20$ & $80.14 \pm 0.58$ & $86.32 \pm 0.63$ & 34.71 \\
\hline Original curcumin & $29.98 \pm 1.31$ & $33.75 \pm 1.55$ & $41.76 \pm 0.63$ & $56.16 \pm 0.58$ & $60.7 \pm 1.27$ & $62.84 \pm 1.53$ & $70.34 \pm 0.63$ & $76.37 \pm 0.71$ & 49.13 \\
\hline 2 & 0 & 0 & 0 & $14.68 \pm 1.50$ & $24.32 \pm 1.20$ & $33.25 \pm 0.63$ & $51.46 \pm 0.58$ & $56.38 \pm 1.20$ & 351.6 \\
\hline 3 & 0 & $11.46 \pm 1.20$ & $16.85 \pm 0.72$ & $21.38 \pm 1.30$ & $37.41 \pm 0.72$ & $58.32 \pm 1.50$ & $61.34 \pm 1.80$ & $67.21 \pm 1.40$ & 200.2 \\
\hline 4 & $31.11 \pm 1.20$ & $36.25 \pm 1.50$ & $42.16 \pm 0.63$ & $57.46 \pm 0.58$ & $61.78 \pm 1.20$ & $65.24 \pm 1.50$ & $72.14 \pm 0.63$ & $79.32 \pm 0.72$ & 47.26 \\
\hline 5 & $18.34 \pm 1.30$ & $25.41 \pm 1.50$ & $35.21 \pm 0.58$ & $44.85 \pm 1.30$ & $51.78 \pm 1.50$ & $59.32 \pm 0.72$ & $62.50 \pm 0.58$ & $71.63 \pm 1.20$ & 95.5 \\
\hline 6 & 0 & 0 & $12.75 \pm 1.30$ & $18.35 \pm 0.58$ & $24.32 \pm 2.10$ & $48.31 \pm 0.63$ & $53.24 \pm 0.58$ & $62.15 \pm 1.20$ & 335.7 \\
\hline 7 & 0 & 0 & $17.35 \pm 1.30$ & $26.84 \pm 0.63$ & $31.85 \pm 2.10$ & $49.37 \pm 0.58$ & $61.72 \pm 1.20$ & $73.24 \pm 1.60$ & 262.75 \\
\hline
\end{tabular}

All determinations were carried out in triplicate manner and values are expressed as the mean \pm S.D. The $\mathrm{IC}_{50}$ value is defined as the concentration of inhibitor to inhibit $50 \%$ of its activity under the assayed conditions. 
The $\mathrm{IC}_{50}$ value was defined as the concentration of alphaamylase inhibitor to inhibit $50 \%$ of its activity under the assay conditions.

In Vitro Anti-inflammatory Assays

Histamine Release Assay

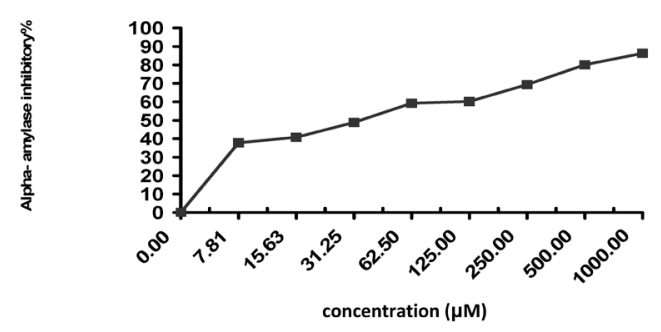

Control(acarbose)

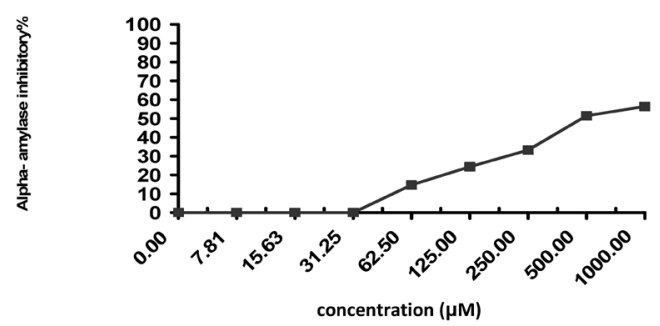

(2)

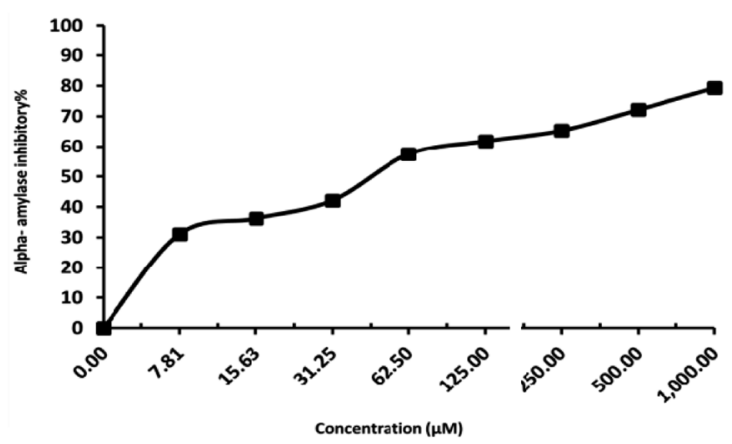

(4)

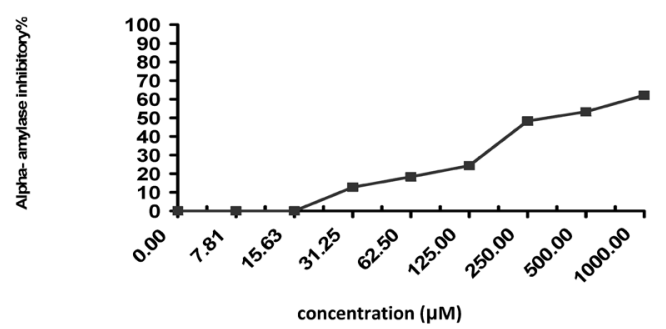

(6)
U937 human monocytes were used to study the effect of samples on histamine release. Approximately 50000 U937 cells were plated in a 96-well cell culture plate (Corning Life Sciences, Lowell, MA, U.S.A.) and treated with various concentration (1000-7.81) of samples, in the presence or absence

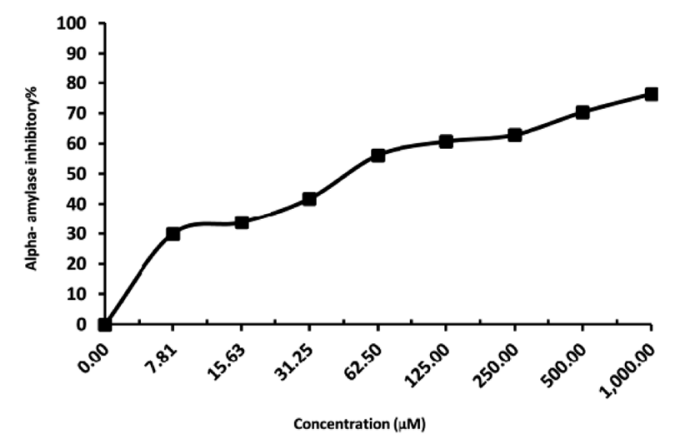

Original curcumin

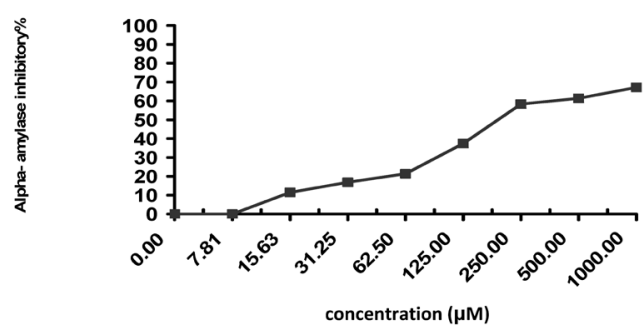

(3)

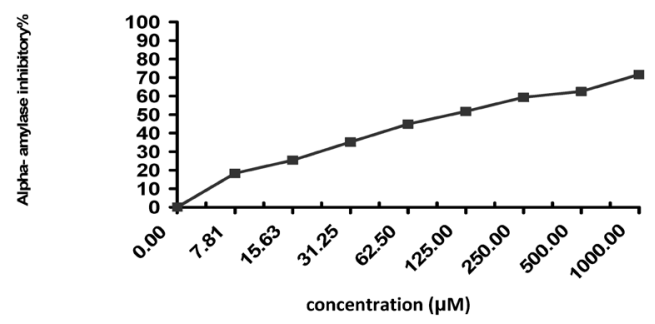

(5)

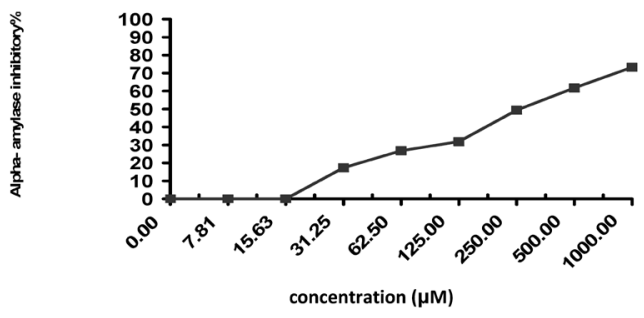

(7)

Fig. 1. $\alpha$-Amylase Inhibitory Effect of Control (Acarbose), Newly Prepared Curcumin Derivatives 2-7 
of $20 \mathrm{~nm}$ phorbol myristate acetate (PMA) (Sigma-Aldrich) for $1 \mathrm{~h}$. The cell culture supernatants collected from either untreated control or treated cultures were clarified at $10000 \mathrm{~g}$ for $5 \mathrm{~min}$ at $4^{\circ} \mathrm{C}$ and assessed for released histamine by a commercially available EIA kit (SPI-Bio, France). ${ }^{25)}$

\section{RESULTS AND DISCUSSION}

The new derivatives were prepared following the reaction sequences depicted in Chart 1.

Treatment of curcumin with acetylacetone in ethanol afforded the cyclohexa-2,4-dienone derivative (2). Its IR $\left(\mathrm{KBr}, \mathrm{cm}^{-1}\right)$ : $3300(\mathrm{O}-\mathrm{H}), 1722,1692(\mathrm{C}=\mathrm{O}) ; 1629(\mathrm{C}=\mathrm{C})$, $1150(\mathrm{C}-\mathrm{O}) .{ }^{1} \mathrm{H}-\mathrm{NMR}$ (DMSO- $\left.d_{6}, \delta \mathrm{ppm}\right): 9.22$ (s, 2H-OH), $7.78-7.25$ (m, 6H, Ar-H), $6.44(\mathrm{~s}, 4 \mathrm{H}, \mathrm{CH}=\mathrm{CH}), 3.04$ (s, 6H, $\left.\mathrm{OCH}_{3}\right), 2.90\left(\mathrm{~s}, 3 \mathrm{H}, \mathrm{CO}-\underline{\mathrm{CH}}_{3}\right) \mathrm{MS}$ : molecular ion peak at $\mathrm{m} / \mathrm{z}$ 432 (8.15\%); molecular fragments at $m / z 77$ (100\%) for $\mathrm{C}_{6} \mathrm{H}_{5}$.

The condensation of curcumin with guanidine. $\mathrm{HCl}$ in ethanol formed-imino-dropyrimidine (3) which showed IR $\left(\mathrm{KBr}, \mathrm{cm}^{-1}\right)$ : $3250(\mathrm{O}-\mathrm{H})$ absence of $(\mathrm{C}=\mathrm{O}) ; 1614(\mathrm{C}=\mathrm{N})$, $1200(\mathrm{C}-\mathrm{O}) .{ }^{1} \mathrm{H}-\mathrm{NMR}$ (DMSO- $\left.d_{6}, \delta \mathrm{ppm}\right): 9.02$ (s, 2H-OH), $7.78-6.85(\mathrm{~m}, 6 \mathrm{H}, \mathrm{Ar}-\mathrm{H}), 6.92(\mathrm{~s}, 4 \mathrm{H}, \mathrm{CH}=\mathrm{CH}), 4.06(\mathrm{~s}, 1 \mathrm{H}$, $\mathrm{C}=\mathrm{NH}), 4.96(\mathrm{~s}, 1 \mathrm{H}, \mathrm{NH}), 3.54\left(\mathrm{~s}, 6 \mathrm{H}, \mathrm{OCH}_{3}\right) ; \mathrm{MS}$ : molecular ion peak at $\mathrm{m} / \mathrm{z} 391$ (15.3\%); molecular fragments at $\mathrm{m} / \mathrm{z} 77$ $(100 \%)$ for $\mathrm{C}_{6} \mathrm{H}_{5}{ }^{+}$.

While condensation with urea and thiourea gave pyrimidin2(1H)-one (4), pyrimidine-2(1H)-thione (6) which spectral data gave the following data for (4). IR $\left(\mathrm{KBr}, \mathrm{cm}^{-1}\right): 3400$ $(\mathrm{OH}-\mathrm{NH}), 1735(\mathrm{C}=\mathrm{O}), 1608(\mathrm{C}=\mathrm{N}), 1200(\mathrm{C}-\mathrm{O}) .{ }^{1} \mathrm{H}-\mathrm{NMR}$ (DMSO- $d_{6}, \delta$ ppm): 7.90-7.20 (m, 6H, Ar-H), 5.01 (s, 2H-OH), 4.11 (s, 1H-NH), 2.89 (s, 1H, CH-CN), 6.03 (s, 4H, CH=CH), 3.41 (s, $\left.6 \mathrm{H}, \mathrm{OCH}_{3}\right)$; MS: molecular ion peak at $\mathrm{m} / \mathrm{z} 392(8.3 \%)$; molecular fragments at $\mathrm{m} / \mathrm{z} 77(100 \%)$ for $\mathrm{C}_{6} \mathrm{H}_{5}{ }^{+}$.

And for (6) IR $\left(\mathrm{KBr}, \mathrm{cm}^{-1}\right): 3420(\mathrm{OH}-\mathrm{NH})$ absence of $(\mathrm{C}=\mathrm{O}), 1608(\mathrm{C}=\mathrm{N}), 1405(\mathrm{C}=\mathrm{S}), 1150 \quad(\mathrm{C}-\mathrm{O}) .{ }^{1} \mathrm{H}-\mathrm{NMR}$ (DMSO- $d_{6}, \delta$ ppm): 9.18 (s, 2H-OH), 7.97-6.89 (m, 6H, Ar-H), $5.84(\mathrm{~s}, 4 \mathrm{H}, \mathrm{CH}=\mathrm{CH}), 4.42(\mathrm{~s}, 1 \mathrm{H}-\mathrm{NH}), 3.56(\mathrm{~s}, 1 \mathrm{H}, \mathrm{CH}-\mathrm{CN})$, $3.24\left(\mathrm{~s}, 6 \mathrm{H}, \mathrm{OCH}_{3}\right)$; MS: molecular ion peak at $\mathrm{m} / \mathrm{z} 408$ (9.05\%); molecular fragments at $m / z 77(100 \%)$ for $\mathrm{C}_{6} \mathrm{H}_{5}{ }^{+}$.

While the condensation of curcumin using active methylene group afforded the pyran-2-one (5) and pyran-3-carbonitrile (7) when treated with ethylacetoacetate and ethylcyanoacetate, respectively.

The spectral data of (5) showed. IR $\left(\mathrm{KBr}, \mathrm{cm}^{-1}\right): 3356$ $(\mathrm{O}-\mathrm{H}), 1720 \quad(\mathrm{C}=\mathrm{O}), 1772 \quad(\mathrm{C}=\mathrm{O}$ lactam $), 1620 \quad(\mathrm{C}=\mathrm{C})$, 1185 (C-O). ${ }^{1} \mathrm{H}-\mathrm{NMR}$ (DMSO- $\left.d_{6}, \delta \mathrm{ppm}\right): 9.12$ (s, 2H-OH), 7.97-7.01 (m, 6H, Ar-H), $5.75(\mathrm{~s}, 4 \mathrm{H}, \mathrm{CH}=\mathrm{CH}), 3.54$ (s, 6H,
$\left.\mathrm{OCH}_{3}\right), 2.27$ (s, 3H, $\left.\mathrm{COCH}_{3}\right), 2.02$ (s, 2H, CH ); MS: molecular ion peak at $\mathrm{m} / \mathrm{z} 436$ (24.5\%); molecular fragments at $\mathrm{m} / \mathrm{z} 77$ (100\%) for $\mathrm{C}_{6} \mathrm{H}_{5}{ }^{+}$.

While for (7). IR $\left(\mathrm{KBr}, \mathrm{cm}^{-1}\right): 3420(\mathrm{OH}), 2150(\mathrm{C} \equiv \mathrm{N})$, $1755(\mathrm{C}=\mathrm{O}), 1611(\mathrm{C}=\mathrm{N}), 1210(\mathrm{C}-\mathrm{O}) .{ }^{1} \mathrm{H}-\mathrm{NMR}\left(\mathrm{DMSO}-d_{6}\right.$, $\delta$ ppm): 9.07 (s, 2H-OH), 7.86-7.01 (m, 10H, Ar-H), 5.79 (s, $4 \mathrm{H}, \mathrm{CH}=\mathrm{CH}), 3.52\left(\mathrm{~s}, 6 \mathrm{H}, \mathrm{OCH}_{3}\right), 2.78$ (s, 1H, CH-CN); MS: molecular ion peak at $\mathrm{m} / z 599(11.02 \%)$; molecular fragments at $m / z 77(100 \%)$ for $\mathrm{C}_{6} \mathrm{H}_{5}{ }^{+}$.

$\alpha$-Amylase Inhibitory Activity by Curcumin Derivatives The $\alpha$-amylase inhibiting activity of curcumin derivatives (27) at different concentrations $(7.81-1000 \mu \mathrm{M})$ was studied, and the results are depicted in the Table 1 and Fig. 1. Compounds $\mathbf{4}$ and $\mathbf{5}$ exhibited significant inhibitory activity against amylase enzyme and was comparable with that of acarbose and original curcumin. Compound 5 showed 18.34 $\pm 1.3,25.41 \pm 1.5$, $35.21 \pm 0.58,44.85 \pm 1.3,51.78 \pm 1.5,59.32 \pm 0.72,62.50 \pm 58$ and $71.63 \pm 1.2 \%$ inhibition at $7.81,15.63,31.25,62.5,125,250$, 500 and $1000 \mu \mathrm{M} / \mathrm{L}$ concentrations, respectively, $\mathrm{IC}_{50}=95.5$. Compound 4 was found to possess pronounced inhibitory activity with $31.11 \pm 1.2,36.25 \pm 1.5,42.16 \pm 0.63,57.46 \pm 0.58$, $61.78 \pm 1.2,65.24 \pm 1.5,72.14 \pm 0.63$ and $79.32 \pm 0.72 \%$ inhibition at $7.81,15.63,31.25,62.5,125,250,500$ and $1000 \mu \mathrm{M} / \mathrm{L}$ concentrations, $\mathrm{IC}_{50}=47.26$. Acarbose and original curcumin showed $86.32 \pm 0.63$ and $76.37 \pm 0.71 \%$ inhibition at $1000 \mu \mathrm{M} / \mathrm{L}$ concentration, $\mathrm{IC}_{50}=34.71$ and 49.13 , respectively. Compound $4\left(\mathrm{IC}_{50}=47.26 \mathrm{~mm}\right)$ and Compound $5\left(\mathrm{IC}_{50}=95.5 \mathrm{~mm}\right)$ are the most potent compared to other compounds. The inhibition of this compound may be due to pyrimidin and pyran rings. ${ }^{12-19)}$

Our results agree with Najafian ${ }^{11)}$ he reported that curcumin inhibited $\alpha$-amylase with an half maximal inhibitory concentration $\mathrm{IC}_{50}$ value $51.32 \mu \mathrm{M}$. Curcumin at different concentrations, i.e., 10, 50, $100 \mu \mathrm{g}$ showed dose dependent effect where as the standard indomethacin at 50 and $100 \mu \mathrm{g}$ exhibited much higher activity. Pancreatic and intestinal glucosidases are the key enzymes of dietary carbohydrates digestion and inhibitors of these enzymes may be effective in retarding glucose absorption. Pancreatic $\alpha$-amylase enzyme inhibition potential of curcumin might be the most promising mechanism for the observed antidiabetic effect. ${ }^{26}$ )

Inhibition of Histamine Release by Curcumin Derivatives The histamine inhibiting activity of curcumin derivatives $(2-7)$ at different concentrations $(7.81-1000 \mu \mathrm{M})$ was studied, and the results are depicted in the Table 2 and Fig. 2. Compounds 5, 6 and 7 exhibited significant inhibitory activity against histamine and was comparable with that of original curcumin. Compound 5 showed 29.35 \pm 2.5 , 36.82 \pm 2.1 ,

Table 2. Histamine Release of Curcumin Derivatives

\begin{tabular}{|c|c|c|c|c|c|c|c|c|c|c|}
\hline Sample conc. $(\mu \mathrm{M})$ & 0 & 7.81 & 15.63 & 31.25 & 62.5 & 125 & 250 & 500 & 1000 & $\mathrm{IC}_{50}$ \\
\hline Original curcumin & $13.11 \pm 0.32$ & $17.56 \pm 1.40$ & $26.26 \pm 1.31$ & $43.17 \pm 1.20$ & $53.33 \pm 0.62$ & $60.19 \pm 1.35$ & $64.29 \pm 0.60$ & $69.35 \pm 1.34$ & $73.37 \pm 1.51$ & 52.26 \\
\hline 2 & 0 & 0 & 0 & 0 & $13.45 \pm 1.2$ & $21.35 \pm 1.5$ & $34.13 \pm 2.2$ & $49.28 \pm 1.5$ & $58.32 \pm 0.58$ & 539.8 \\
\hline 3 & 0 & 9.25 & 17.36 & 24.32 & $33.85 \pm 1.6$ & $46.34 \pm 1.5$ & $52.41 \pm 0.58$ & $55.62 \pm 1.2$ & $61.85 \pm 0.63$ & 200.37 \\
\hline 4 & 0 & $6.38 \pm 1.5$ & $13.25 \pm 0.85$ & $19.35 \pm 1.2$ & $31.25 \pm 0.72$ & $46.31 \pm 0.72$ & $53.18 \pm 0.58$ & $59.32 \pm 1.2$ & $71.34 \pm 1.5$ & 192.13 \\
\hline 5 & 0 & $29.35 \pm 2.5$ & $36.82 \pm 2.1$ & $41.85 \pm 1.6$ & $58.41 \pm 1.3$ & $62.41 \pm 0.58$ & $68.72 \pm 1.2$ & $74.65 \pm 2.1$ & $79.31 \pm 1.8$ & 46.6 \\
\hline 6 & $9.35 \pm 1.2$ & $11.32 \pm 0.63$ & $28.41 \pm 0.72$ & $52.34 \pm 1.2$ & $56.32 \pm 0.58$ & $61.91 \pm 0.72$ & $66.81 \pm 1.5$ & $70.14 \pm 2.1$ & $73.25 \pm 1.6$ & 29.7 \\
\hline 7 & 0 & $23.58 \pm 1.5$ & $36.28 \pm 1.2$ & $52.13 \pm 1.2$ & $54.32 \pm 0.63$ & $60.17 \pm 1.2$ & $63.25 \pm 0.58$ & $76.34 \pm 1.2$ & $82.31 \pm 1.5$ & 29.15 \\
\hline
\end{tabular}

All determinations were carried out in triplicate manner and values are expressed as the mean \pm S.D. The $\mathrm{IC}_{50}$ value is defined as the concentration of inhibitor to inhibit $50 \%$ of its activity under the assayed conditions. 


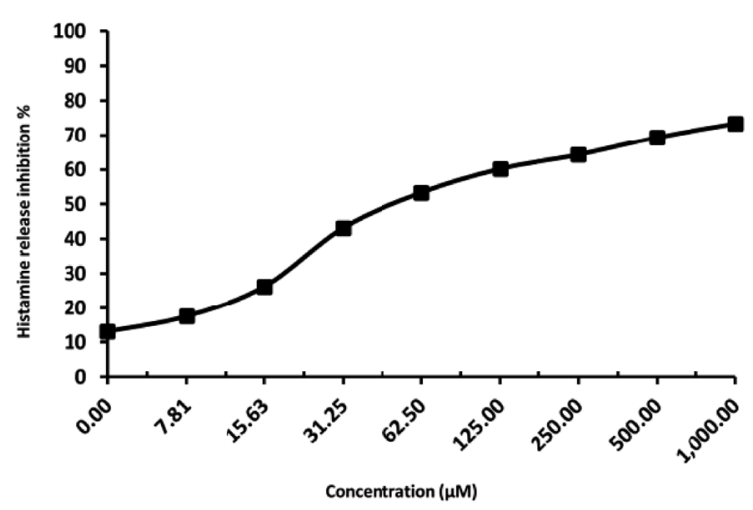

\section{Original curcumin}

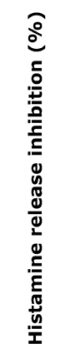

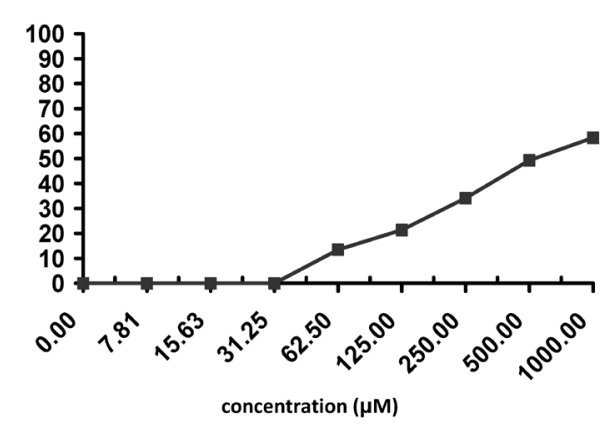

(2)

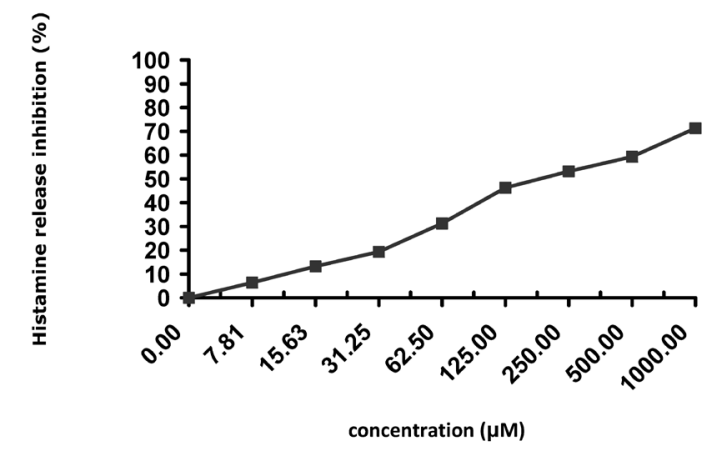

(4)

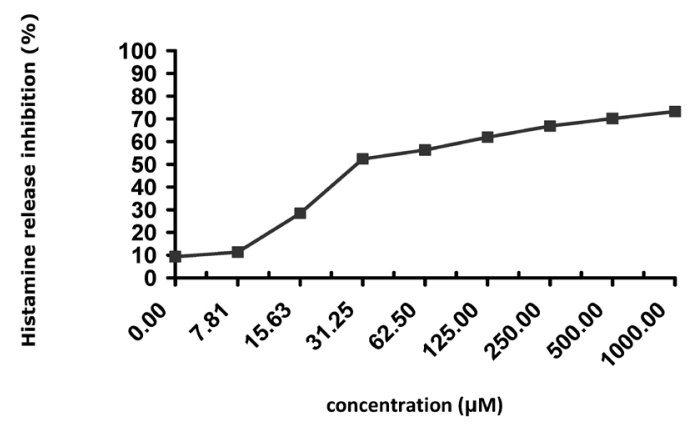

(6)

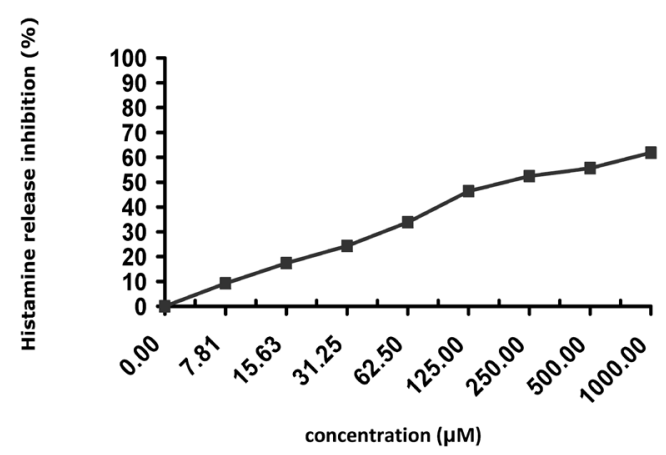

(3)

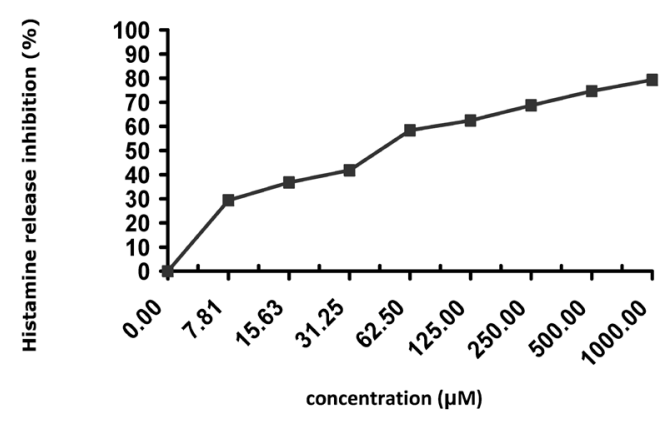

(5)

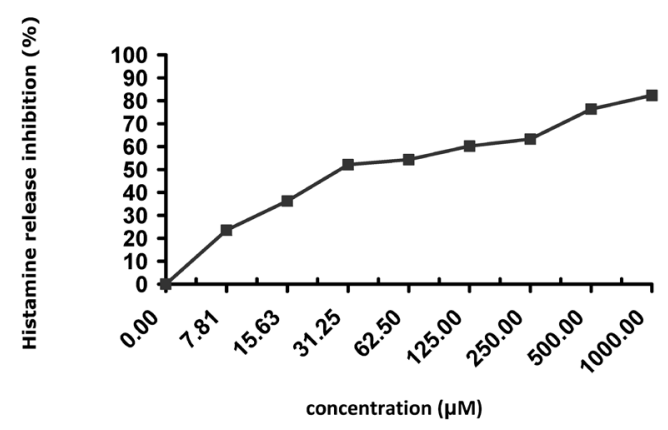

(7)

Fig. 2. Histamine Release of Curcumin Derivatives (2-7) 
$41.85 \pm 1.6, \quad 58.41 \pm 1.3, \quad 62.41 \pm 0.58, \quad 68.72 \pm 1.2, \quad 74.65 \pm 2.1$ and $79.31 \pm 1.8 \%$ inhibition at $7.81,15.63,31.25,62.5,125$, 250,500 and $1000 \mu \mathrm{m} / \mathrm{L}$ concentrations, respectively, $\mathrm{IC}_{50}=46.6$. Compounds 6 and 7 were found to possess pronounced inhibitory activity with (11.32 \pm 0.63 and $23.58 \pm 1.5)$, $(28.41 \pm 0.72$ and $36.28 \pm 1.2),(52.34 \pm 1.2$ and $52.13 \pm 1.2)$, (56.32 \pm 0.58 and $54.32 \pm 0.63),(61.91 \pm 0.72$ and $60.17 \pm 1.2)$, $(66.81 \pm 1.5$ and $63.25 \pm 0.58),(70.14 \pm 2.1$ and $76.34 \pm 1.2)$ and $(73.25 \pm 1.6$ and $82.31 \pm 1.5) \%$ inhibition at $7.81,15.63,31.25$, $62.5,125,250,500$ and $1000 \mu \mathrm{M} / \mathrm{L}$ concentrations, respectively, $\mathrm{IC}_{50}=29.7$ and 29.15 , respectively. Original curcumin showed $73.37 \pm 1.51 \%$ inhibition at $1000 \mu \mathrm{M} / \mathrm{L}$ concentration, $\mathrm{IC}_{50}=52.26$. Compounds $5\left(\mathrm{IC}_{50}=46.6 \mu \mathrm{M}\right), 6\left(\mathrm{IC}_{50}=29.7 \mu \mathrm{M}\right)$ and $7\left(\mathrm{IC}_{50}=29.15 \mu \mathrm{M}\right)$ are the most potent compared to other compounds. The inhibition of this compound may be due to pyrimidin and pyran rings. ${ }^{12-19)}$

Curcumin has been reported to have anti-allergic effects and can inhibit the release of histamine from mast cells. ${ }^{27)}$ The histamine release from compound 48/80-treated RPMCs was reduced in a dose-dependent manner by curcumin (58 and $80 \%$ inhibition at 25 and $50 \mu \mathrm{M}$, respectively). Curcumin inhibits mast cell-mediated anaphylactoidresponses by suppressing histamine release from RPMCs. ${ }^{28}$ )

Histamine levels were found to be raised by 8 fold from the baseline upon induction with PMA. Curcumin when treated at different concentration 10,250 and $1000 \mathrm{ng} \mathrm{mL}^{-1}$ showed decrease in the percentage rise in histamine levels by 82.70 , 67.51 and $55.69 \%$ from U937 cells. ${ }^{25}$ Curcumin also suppressed the immunoglobulin E (IgE)-dependent PSA reaction in a mast cell-dependent in vivo model of systemic allergic reaction $^{29}$ ) with a potency equivalent to that of the $\mathrm{H} 1$ histamine antagonist. ${ }^{30)}$

\section{CONCLUSION}

From this study we have synthesized new pyrimidine, pyranone, cyclohexanone derivatives from curcumin and proved its structure by different spectral data. This newly prepared compounds had showed remarkable biological activity as antidiabetic and anti-histamine. The curcumin derivatives (4 and $\mathbf{5}$ ) showed a prominent inhibition of $\alpha$-amylase with $\mathrm{IC}_{50}=47.26$ and 95.5, respectively. On the other hand, curcumin derivatives (5, 6 and 7) exhibited significant inhibitory activity as anti-histamine.

Conflict of Interest The authors declare no conflict of interest.

\section{REFERENCES}

1) Maheshwari RK, Singh AK, Gaddipati J, Srimal RC. Multiple biological activities of curcumin: a short review. Life Sci., 78, 20812087 (2006).

2) Ram A, Das M, Ghosh B. Curcumin attenuates allergen-induced airway hyper responsiveness in sensitized guinea pigs. Biol. Pharm. Bull., 26, 1021-1024 (2003).

3) Kurup VP, Barrios CS, Raju R, Johnson BD, Levy MB, Fink JN. Immune response modulation by curcumin in a latex allergy model. Clin. Mol. Allergy, 5, 1-12 (2007)

4) Matsuda H, Tewtrakul S, Morikawa T, Nakamura A, Yoshikawa M. Anti-allergic principles from thai zedoary: structural requirements of curcuminoids for inhibition of degranulation and effect on the release of TNF-alpha and IL-4 in RBL-2H3 cells. Bioorg. Med. Chem., 12, 5891-5898 (2004).

5) Suzuki M, Nakamura T, Iyoki S, Fujiwara A, Watanabe $Y$, Mohri $\mathrm{K}$, Isobe K, Ono K, Yano S. Elucidation of anti-allergic activities of curcumin-related compounds with a special reference to their antioxidative activities. Biol. Pharm. Bull., 28, 1438-1443 (2005).

6) Araujo CAC, Leon LL. Biological activities of Curcuma longa L. Mem. Inst. Oswaldo Cruz, 96, 723-728 (2001).

7) Aggarwal B, Kumar A, Bharti A. Anticancer potential of curcumin: preclinical and clinical studies. Anticancer Res., 23 (1A), 363-398 (2003).

8) Nugroho AE, Yuniarti N, Istyastono EP, Supardjan MK, Hakim L. Anti-allergic effects of 1,5-bis(4'-hydroxy-3'-methoxyphenyl)-1,4pentadiene-3-one on mast cell-mediated allergy model. Malaysian Journal of Pharmaceutical Sciences, 7, 51-71 (2009).

9) Najafian M. Effect of curcumin on metabolism of lipids in streptozotocin induced diabetic and normal rats. Biomed. Pharm. J., 7, 383-391 (2014).

10) Najafian M. A review of $\alpha$-amylase inhibitors on weight loss and glycemic control in pathological state such as obesity and diabetes. Comp. Clin. Pathol., 24, 219 (2015).

11) Najafian M. The effects of curcumin on alpha amylase in diabetics rats. Zahedan Journal of Research in Medical Science, 15, 29-34 (2015).

12) Barakat A, Islam MS, Al-Majid AM, Ghabbour HA, Yousuf $S$, Ashraf M, Shaikh NN, Iqbal Choudhary M, Khalil R, Ul-Haq Z. Synthesis of pyrimidine-2,4,6-trione derivatives: anti-oxidant, anticancer, $\alpha$-glucosidase, $\beta$-glucuronidase inhibition and their molecular docking studies. Bioorg. Chem., 68, 72-79 (2016).

13) Faycel J, Fethi B, Ismail A, Jamoussi B, Jameleddine K. Synthesis and biological activity of novel benzothiazole pyridine derivatives. J. Appl. Chem., 7, 62-66 (2014).

14) Virupakshi P, Kondra S, Ravindranath L, Latha J. Design, synthesis, characterization and biological activity of novel thieno[2,3-d]pyrimidine derivatives. Ind. J. Adv. Chem. Sci., 5, 30-42 (2017).

15) Rani J, Kumar S, Saini M, Mundlia J, Verma PK. Biological potential of pyrimidine derivatives in a new era. Rese. Chem. Inter., $\mathbf{4 2}$, 6777-6804 (2016).

16) Nahed F, Mona S, Galal H, Azza M, Sara N. The use of pyridazinethione derivative in the preparation of some new heterocyclic compounds with expected antitumor activity. J. Chem. Pharm. Res., 4, 4562-4569 (2012).

17) Bransová J, Brtko J, Uher M, Novotný L. Antileukemic activity of 4-pyranone derivatives. Int. J. Biochem. Cell Biol., 27, 701-706 (1995).

18) McGlacken GP, Fairlamb IJS. 2-Pyrone natural products and mimetics: isolation, characterization and biological activity. Nat. Prod. Rep., 22, 369-385 (2005).

19) Schiller R, Tichotová L, Pavlík J, Buchta V, Melichar B, Votruba I, Kuneš J, Spulák M, Pour M. 3,5-Disubstituted pyranone analogues of highly antifungally active furanones: conversion of biological effect from antifungal to cytostatic. Bioorg. Med. Chem. Lett., 20, 7358-7360 (2010).

20) Schäberle TF. Schäberle, Biosynthesis of $\alpha$-pyrones. Beilstein $J$. Org. Chem., 12, 571-588 (2016).

21) Sara N. Synthesis of some new cyclohexene carboxylic acid derivatives as potent antitumor agents. J. Chem. Pharm. Res., 5, 168-177 (2013).

22) Nehad A, Manal M, Nesreen S, Rasha Z, Nadia RA. Synthesis of some pyridine, pyrimidine and cyclohexenone derivatives as antibacterial agents. Int. J. Innu. Res. Sci. Eng. Technol., 3, 8517-8529 (2014).

23) Abdullah SA. Mechanochemical synthesis of cyclohexenones and indazoles as potential antimicrobial agents. Res. Chem. Int., 42, 5457-5477 (2016)

24) Ingrid F, Mattias FM. Traditionally used plants in diabetes therapy: 
phytotherapeutics as inhibitors of alpha-amylase activity. Sociedade Brasileira de Farmacognosia Brazilian Journal of Pharmacognosy, 16, 1-5 (2006).

25) Venkata M, Sripathy R, Anjana D, Somashekara N, Krishnaraju A, Krishanu S, Murali M, Rama Verma S, Ramchand CN. In silico, in vitro and in vivo assessment of safety and anti-inflammatory activity of curcum. Am. J. Infect. Dis., 8, 26-33 (2012).

26) Satapathy T, Panda PK. Evaluation of in vitro antioxidant, anti inflammatory, anti diabetic potential of curcumin. Indo American Journal of Pharm. Research, 3, 2808-2818 (2013).

27) Nugroho AE, Yuniarti N, Istyastono EP, Supardjan, Maeyama K, Hakim L. Anti-allergic effects of 1,5-bis(4'-hydroxy-3'methoxyphenyl)-1,4-pentadiene-3-one on mast cell-mediated allergy model. Malaysian Journal of Pharmaceutical Sciences, 7, 51-71
(2009).

28) Choi YH, Yan GH, Chai OH, Song CH. Inhibitory effects of curcumin on passive cutaneous anaphylactoid response and compound 48/80-induced mast cell activation. Anat. Cell Biol., 43, 36-43 (2010)

29) Wershil BK, Mekori YA, Murakami T, Galli SJ. ${ }^{125}$ I-fibrin deposition in IgE-dependent immediate hypersensitivity reactions in mouse skin. Demonstration of the role of mast cells using genetically mast cell-deficient mice locally reconstituted with cultured mast cells. J. Immunol., 139, 2605-2614 (1987).

30) Li X, Lu Y, Jin Y, Son JK, Lee SH, Chang HW. Curcumin inhibits the activation of immunoglobulin E-mediated mast cells and passive systemic anaphylaxis in mice by reducing serum eicosanoid and histamine levels. Biomol. Ther., 22, 27-34 (2014). 